\title{
The Bushido as allied: Japanese Warriors' Anthropology in Fascist Italy cultural magazines (1941-1943)
}

\author{
Sergio RAIMONDO ${ }^{*}, 2$, Valentina DE FORTUNA ${ }^{3}$ \\ ${ }^{1}$ University of Cassino and South Lazio (Italy) \\ ${ }^{2}$ Area Discipline Orientali Unione Italiana Sport per Tutti (Italy) \\ ${ }^{3}$ Free Lance Translator (Italy)
}

\section{5th IMACSSS World Scientific Congress Abstracts, Rio Maior (Portugal), October 6-8 Section: Historical, sociological and philosophical issues of MA\&CS Type: Oral communication}

\section{Introduction}

After the signing of the alliance among Japan, Germany and Italy governments in September 1940, several journals arose in order to spread the Japanese culture among people who knew very little about Italy's new allied.

Between January 1941 and August 1943 the most important publication was Yamato, an ItalianJapanese monthly magazine entirely devoted to this goal. Although it was deeply oriented towards military-based policies, it helped spread the Japanese culture through a great variety of texts and images concerning Japanese art, language, habits and warlike traditions.

Other magazines shared the same goal as Yamato magazine: in 1940 the first Italian scientific publication called Sapere (Knowledge) dedicated a special monographic issue to the cause as well as the magazine Civiltà (Civilization) which published several articles on the same theme in 1942.

\section{Methodology}

The numerous textual and iconographical references in the 32 booklets of the monthly magazine Yamato, concerning the Japanese warriors' anthropology have been compared to the articles, treating the same issue, on the magazines Sapere and Civiltà, as well as to the few Italian monographies on the same theme (Degli Uberti, 1933).

This subject has also been compared to the first Italian cultural production, concerning Japan, which dated back to the first decades of the $20^{\text {th }}$ century. Moreover different intellectuals' biographies of those times have been deeply.

\section{Results}

Comparing to each other the anthropological references about Japan in the afore mentioned Italian magazines, all published during the Second World War, we can notice a significant ideological homogeneity of thesis. This can be explained through their writers' common sharing of the militaristic, hierarchical and totalitarian doctrine of the Fascist Regime.

It is not surprisingly that the main Yamato editors also signed articles on other magazines becoming a clear example of the intellectual and political continuity between Fascist period and Postwar period.

The Fascist ideology can be summarized in the Bushido concept, as Inazo Nitobe (1916) defined it. This concept was already known in Italy in 1917, far before Fascism, thanks to a translation made

${ }^{*}$ Email: sergio.raimondo@beniculturali.it

(C) 2016 Universidad de León. www.unileon.es 
by Bartolomeo Balbi, an active popularizer of the Japanese culture, with his own publishing house and a deep interest in Japanese martial tradition and military subjects (Balbi, 1916a, 1916b, 1916c; Sakurai, 1913).

Very successful was, and would have been in the future, his 1916 translation of the epic tale 47 Rōnin (Mitford, 1916), already known in Italy since 1908 (Boari, 1908).This epic tale was resumed in the already mentioned magazines of the $40 \mathrm{~s}$, principally to underline how heroism was manifestation of loyalty.

It is not to forget that probably the Italian audience had already developed a particular sensibility to these themes thanks to the well-established success of the melodrama Madama Butterfly, first brought on stage in 1904 (Centro Studi Giacomo Puccini, 2005; Illica, Giacosa, \& Puccini, 1904; Ricordi, 1904).

Effectively the "loyalty" theme can be found both in the heroes of the epic tale - 47 Rōnin - and in the moral of the unlucky heroine of the melodrama, Madama Butterfly.

Moreover, Puccini asked the well-known actress Sada Yacco and the wife of the Japanese ambassador in Italy an advice for Japanese stage costumes.

The theme concerning the connection between loyalty and honor was then enhanced by Benito Mussolini: in 1928 he sent to Japan an ancient roman column, found in Pompeii's excavations, to celebrate the ritual suicide of the young men of Byakkotai. Those men in the 19th century committed suicide to give prove of their loyalty to Shogun power, who didn't want the imperial power to be restored because it was too submissive to Western Nations (Aloisi, 1941; Martinelli, 2003).

Mussolini knew about the Byakkotai event thanks to Hurashiki Shimoi, a scholar man who had fought together with the Italian troops during the Great War, giving soldiers karate lessons (Bernardini Napoletano, 2015; Doi, 2014; Hofman, 2015; Merlino, 2003; Shimoi, 1919).

His presence as teacher in the Istituto Orientale di Napoli (University of Naples L'Orientale) contemporary to the presence of Balbi is a meaningful coincidence that marks a deep mutual intellectual influence (Zagra, 1996:77).

\section{Discussion and conclusion}

Comparing the different Italian cultural articles, written after the Russian-Japanese war and concerning the early $20^{\text {th }}$ century Japan, we can see how Italian perception of the Japanese anthropology did not change over time and how its features will re-appear in the 40s under the influence of the Italian-Japanese coalition. However Italian perception of the Japanese anthropology didn't follow the giapponismo (Japan-oriented) trend of the late 19th century which spread in other countries such as France, England and Germany (Arzeni, 1987; Buttò, 1996).

Giacinto Auriti, author and editor of Yamato and other magazines as well as Italian Ambassador in Japan from 1933 to 1940, had a key role in pushing for a convergence between the two countries. Effectively, in 1935, he drew Shimoi - whose link with the Japanese radical right wing was renowned (Ferretti, 1995) into his policy.

So, according to Balbi and Yamato and other magazines' fascist editors, Bushido became the essence of the Japanese military and national identity that Fascist Italy took as example for mass education.

Japanese authors were actually those who wrote on Italian magazines and underlined the similarities between Japanese and Fascist spirits.

The linking concepts among all these intellectual productions were Loyalty and the resulting Ultimate Sacrifice, both featuring 47 Rōnin and Madama Butterfly.

Some of these stereotypes will re-appear after the war and until recent times in popular culture (Nolitta, Bignotti \& Ferri, 1975a,b) and in mass perception of Japanese martial arts (Raimondo, 2008). 


\section{References}

Akiyama, T. (1942). Un capolavoro quattrocentesco della pittura di guerra. Yamato. Mensile italogiapponese, II(1), 48-49.

Aloisi, P. (1941). L'eroico episodio delle "Tigri Bianche". Yamato. Mensile italo-giapponese", I(5), 137138

Arzeni, F. (1987). L'immagine e il segno. Il giapponismo nella cultura europea tra Ottocento e Novecento. Bologna: Il Mulino.

Balbi, B. (1916a). Come il Giappone prepara le vittorie?. Napoli: Casa editrice Italo-cino giapponese Iwakan Hakkosh.

Balbi, B. (1916b). I canti dei fiori e I canti delle spade. Napoli: Casa Ed. Italo-Cino- Giapponese.

Balbi, B. (1916c). La psiche e la virtù bellica del popolo giapponese:Yamato-damashii Napoli: Casa editrice italo-cino giapponese.

Bernardini Napoletano, F. (2015). Ungaretti. Da una lastra di deserto. Lettere dal fronte a Gherardo Marone. Milano: Mondadori.

Boari, E. (1908). Racconti del vecchio Giappone. Milano: Sonzogno.

Buttò, S. (1996). Il Giappone svelato: la "provincia" italiana e una moda europea. In Biblioteca Nazionale Centrale Vittorio Emanuele II - Roma, Pagine dall'Oriente. Libri cinesi e giapponesi della Biblioteca Nazionale, Bardi, Roma, 47-74.

Centro studi Giacomo Puccini (2005). Madama Butterfly, fonti e documenti della genesi. Lucca: Maria Pacini Fazzi.

Degli Uberti, U. (1933). Nei mari dell'Estremo Oriente. La guerra navale russo-giapponese 1904-1905, Milano: Corbaccio dall'Oglio.

Doi, H. (2014). Harukichi Shimoi e l'avanguardia napoletana. In M.K. Gesuato (Ed.), Ricerca, scoperta, innovazione: l'Italia dei saperi (pp. 43-51). Tokyo: Istituto Italiano di Cultura.

Ferretti, V. (1995). Il Giappone e la politica estera italiana 1935-41. Milano: Giuffrè.

Hofmann, R. (2015). The Fascist Effect: Japan and Italy, 1915-1952. Ithaca (USA): Cornell University Press.

Illica, L., Giacosa, G. \& Puccini, G. (1904). Madama Butterfly (da John Long e David Belasco). Tragedia giapponese. Milano: Ricordi.

Martinelli, L. (2003). La colonna del duce per i samurai. Il Sole 24 Ore Domenica, 135, 28.

Merlino, F.V. (2003). Il sodalizio Shimoi-D'Annunzio. in A. Tamburello (Ed.), Italia-Giappone 450 anni. Roma - Napoli: Istituto italiano per l'Africa e l'Oriente - Università degli studi di Napoli L'Orientale.

Mitford, A.B. (1916). I racconti del vecchio Giappone. I quarantasette ronin (transl. B.Balbi). Napoli: Casa Ed. Italo-Cino-Giapponese.

Nitobe, I. (1917). Bushido: l'anima del Giappone (transl. B.Balbi). Napoli: Casa Ed. Italo-CinoGiapponese.

Nolitta, G., Bignotti, F. \& Ferri, G. (1975). Arrivano i Samurai. Zagor, 117.

Nolitta, G., Bignotti, F. \& Ferri, G. (1975). La scure e la sciabola. Zagor, 118.

Raimondo, S. (2008). Martial arts and civil society in Italy during Sixties and Seventies. IDOMovement for Culture, 8, 38-44.

Ricordi, G. (1904). Rosina Storchio nell'opera di Madama Butterfly. Musica e musicisti, 59/5, 189192.

Sakurai, T. (1913). Nikudan: proiettili umani. Episodi dal vero dell'assedio di Port Arthur (transl. B.Balbi, Sekai Koron). Tokyo - Grottaferrata: Tipografia Italo Orientale.

Shimoi, H. (1919). La guerra italiana, impressioni di un giapponese. Napoli: Libreria della Diana.

Zagra, G. (1996). Suggestioni dal Giappone nel panorama letterario italiano tra '800 e '900. In Biblioteca Nazionale Centrale Vittorio Emanuele II - Roma, Pagine dall'Oriente. Libri cinesi e giapponesi della Biblioteca Nazionale, Bardi, Roma, 75-96.

Key words: Fascist Ideology; Japanese Martial Tradition; Heroism and Loyalty. 